\title{
A GAS-DIFFUSION CATHODE COATED WITH OXIDE-CATALYST FOR POLYMER ELECTROLYTE FUEL CELLS USING NEITHER PLATINUM CATALYST NOR CARBON CATALYST-SUPPORT
}

\author{
Y. Takasu*, H. Fukunaga, H.-S. Yang, T. Ohashi, \\ M. Suzuki and W. Sugimoto
}

Department of Materials and Chemical Engineering, Faculty of Textile Science and Technology, Shinshu University, 3-15-1 Tokida, Ueda, Nagano 386-8567, Japan ytakasu@shinshu-u.ac.jp (Y.T.)

\begin{abstract}
To overcome the fundamental disadvantages of conventional cathodes for polymer electrolyte fuel cells (PEFCs), such as dissolution and migration of platinum-based catalysts and consumption of the carbon catalyst-support, a substantially novel gas-diffusion cathode has been proposed. The electrode was made of a porous oxide catalyst, which was coated on the inner and outer surfaces of a macro-porous titanium sheet substrate, using neither a platinum catalyst nor carbon catalyst-support. The suitability of this cathode for PEFCs, tested using a highly porous iridium oxide strongly coated on the macro-porous titanium sheet substrate, was confirmed by successful power generation. The gas-diffusion electrode functioned not only as the cathode but also as an anode of a PEFC.
\end{abstract}

Keywords: gas-diffusion electrode, cathode, ORR, iridium oxide, PEFC 


\section{INTRODUCTION}

Polymer electrolyte fuel cells (PEFCs) have attracted considerable research interest worldwide because they are promising not only for clean energy applications but also for distributed power supplies[1-3]. Platinum-based cathode catalysts loaded on carbon black or carbon nanotubes, e.g., $\mathrm{Pt} / \mathrm{C}, \mathrm{PtCo} / \mathrm{C}$, or $\mathrm{Pt} / \mathrm{Au} / \mathrm{C}[1-4]$, are likely to have serious unresolved disadvantages, such as dissolution and migration of catalyst metal and consumption of the carbon support, especially when PEFCs are operated under fluctuating loads[1-3, 5-7]. Another issue that must be considered is that the consumption of the carbon catalyst-support will increase significantly when PEFCs are operated under conditions of widely fluctuating loads and at higher temperature (e.g., $\sim 150^{\circ} \mathrm{C}$ ). To enhance the reliability of PEFCs, the gas-diffusion cathode responsible for the oxygen reduction reaction (ORR) must be radically improved. Although various non-platinum cathode catalysts have been proposed[3, 8-19], they generally use a carbon material as the cathode catalyst itself[8-12] or to provide electric conductivity to the less-conductive cathode catalyst particles such as oxides and oxycarbonitrides[13-15, 18]. However, the carbon in the catalyst layer of these non-platinum cathode catalysts can be unstable during power generation.

Here, we present a novel concept and a few basic results of a novel gas-diffusion cathode made of a highly porous oxide catalyst, which was strongly coated on the inner and outer surfaces of a macro-porous titanium sheet substrate, MPTi, using neither a platinum catalyst nor carbon support. The applicability of this electrode as a gas-diffusion anode for PEFCs will also be examined. 


\section{EXPERIMENTAL}

\section{Preparation of $\mathrm{HP}-\mathrm{IrO}_{2} / \mathrm{Ti}$ electrode of the $\mathrm{RDE}$ equipment}

The highly porous iridium oxide electrode with a Ti disk substrate, $\mathrm{HP}-\mathrm{IrO}_{2} / \mathrm{Ti}$, was prepared by almost the same procedure using a titanium disk substrate reported in the previous papers[16, 17]. First, a removable Ti disk (6 $\mathrm{mm}$ in diameter) of homemade rotating disk electrode (RDE) equipment, developed in this study, was etched in oxalic acid solution at $80^{\circ} \mathrm{C}$ for $2 \mathrm{~h}$. Next, a predetermined quantity of $1.2 \mu \mathrm{L}$ solution (1-butanol solution containing $0.5 \mathrm{M} \mathrm{IrCl}_{3}$ ) was dropped onto the top surface of the $\mathrm{Ti}$ disk. Then the disk was dried $\left(60^{\circ} \mathrm{C}, 10 \mathrm{~min}\right)$ and heated $\left(550^{\circ} \mathrm{C}, 10 \mathrm{~min}\right)$ in air to coat the top surface of the disk with a dense and thin $\mathrm{IrO}_{2}$ interface to prevent the electrolyte from touching the $\mathrm{Ti}$ substrate directly. After the procedure, $1.2 \mu \mathrm{L}$ of solution (1-butanol solution containing $0.35 \mathrm{M} \mathrm{IrCl}_{3}$ and 0.15 or $0.13 \mathrm{M} \mathrm{La}\left(\mathrm{NO}_{3}\right)_{3} \cdot 6 \mathrm{H}_{2} \mathrm{O}$ ) was dropped onto the $\mathrm{IrO}_{2}$-coated Ti disk followed by drying $\left(60^{\circ} \mathrm{C}, 10 \mathrm{~min}\right)$ and calcination $\left(450^{\circ} \mathrm{C}, 10 \mathrm{~min}\right)$ in air. The procedure was repeated twice, and all traces of lanthanum species were then completely removed using $0.5 \mathrm{M} \mathrm{H}_{2} \mathrm{SO}_{4}$ at $60^{\circ} \mathrm{C}$ for $10 \mathrm{~h}$. The electrode was then washed with distilled water followed by drying in air at $60^{\circ} \mathrm{C}$ for 30 min. A typical amount of $\mathrm{HP}-\mathrm{IrO}_{2}$ loaded on the titanium disk determined by gravimetry was $1.1 \mathrm{mg} \mathrm{cm}^{-2}$. Finally, $10 \mu \mathrm{L}$ of a $0.025 \mathrm{wt} \%$ dispersion of an ionomer $\left(\mathrm{Nafion}^{\circledR}\right.$, Aldrich) in a $\mathrm{C}_{2} \mathrm{H}_{5} \mathrm{OH} / \mathrm{H}_{2} \mathrm{O}\left(\mathrm{C}_{2} \mathrm{H}_{5} \mathrm{OH}: \mathrm{H}_{2} \mathrm{O}=4: 1\right.$, volume ratio) mixture was dropped onto the electrode surface, and the electrode was dried at $60^{\circ} \mathrm{C}$ for $1 \mathrm{~h}$ in air and at room temperature for one night in the vacuum condition. Although the $\mathrm{HP}-\mathrm{IrO}_{2}$ layer adhered strongly to the Ti disk surface, the oxide layer was coated with the ionomer to make the 
electrode condition similar to that of the MEA described below.

Electrochemical measurements for the ORR and $\mathrm{HOR}$ on the $\mathrm{HP}-\mathrm{IrO}_{2} / \mathrm{Ti}$ electrode with a rotating disk electrode (RDE) equipped with a removable titanium disk electrode

A beaker-type electrolytic cell for the RDE was used. A bundle of carbon fibers, instead of a Pt plate, was used as the counter-electrode to avoid the deposition of Pt onto the test electrode through dissolution. A Luggin capillary, connected to a hydrogen electrode as a reference electrode, was placed in front of the working electrode at a distance of $2 \mathrm{~mm}$. For the ORR and the HOR (hydrogen oxidation reaction) experiments, highly pure oxygen gas and highly pure hydrogen gas were bubbled into a $0.1 \mathrm{M} \mathrm{HClO}_{4}$ solution at $30^{\circ} \mathrm{C}$, respectively. Prior to the voltammetry, all the $\mathrm{HP}-\mathrm{IrO}_{2} / \mathrm{Ti}$ electrodes used in this study were pre-treated in electrolytic solution by sweeping the electrode potential between $0.05 \mathrm{~V}$ and $1.5 \mathrm{~V}$ vs. RHE at $50 \mathrm{mV} \mathrm{s}^{-1}$ for $30 \mathrm{~min}$.

Electrochemical measurements for the ORR by rotating ring disk electrode method $(\boldsymbol{R R D E})$

Rotating ring disk electrode (RRDE) equipment with a glassy carbon disk (GC) electrode (6 mm in diameter), a platinum ring electrode, and a bundle of carbon cloth counter electrode and hydrogen electrode was used to elucidate the reaction process for the ORR on the HP- $\mathrm{IrO}_{2}$ cathode. Since it was difficult to replace the GC electrode of the RRDE equipment with a removable titanium disk electrode, $\mathrm{HP}-\mathrm{IrO}_{2}$ powder was put on the GC electrode. The HP-IrO 2 powder was prepared as follows: a MPTi sheet was soaked in the coating solution (1-butanol solution containing $0.5 \mathrm{M} \mathrm{IrCl}_{3}$ and 0.21 
$\left.\mathrm{M} \mathrm{La}\left(\mathrm{NO}_{3}\right)_{3} \cdot 6 \mathrm{H}_{2} \mathrm{O}\right)$ followed by drying $\left(60^{\circ} \mathrm{C}, 10 \mathrm{~min}\right)$ and calcination $\left(300^{\circ} \mathrm{C}, 10 \mathrm{~min}\right)$ in air. This procedure was repeated twice. The electrode was then ultra-sonicated in distilled water to remove the $\mathrm{IrO}_{2}-\mathrm{La}_{2} \mathrm{O}_{3}$ particles from the MPTi sheet followed by filtration. The filtrated $\mathrm{IrO}_{2}-\mathrm{La}_{2} \mathrm{O}_{3}$ particles were dried and calcined $\left(450^{\circ} \mathrm{C}, 20 \mathrm{~min}\right)$ in air, and then all traces of lanthanum species were removed using $0.5 \mathrm{M} \mathrm{H}_{2} \mathrm{SO}_{4}$ at $60^{\circ} \mathrm{C}$ for $10 \mathrm{~h}$ to prepare $\mathrm{HP}-\mathrm{IrO}_{2}$ fine particles. After filtration, the $\mathrm{HP}-\mathrm{IrO}_{2}$ particles were ground and then washed with distilled water followed by drying in air at $60^{\circ} \mathrm{C}$ for 30 min. A small amount of $\mathrm{HP}-\mathrm{IrO}_{2}$ particles $(0.2 \mathrm{mg})$ was put on the $\mathrm{GC}$ electrode of the RRDE using a dispersion of $\mathrm{HP}-\mathrm{IrO}_{2}$ in water. Finally, $10 \mu \mathrm{L}$ of a $0.025 \mathrm{wt} \%$ dispersion of the ionomer in a $\mathrm{C}_{2} \mathrm{H}_{5} \mathrm{OH} / \mathrm{H}_{2} \mathrm{O}\left(\mathrm{C}_{2} \mathrm{H}_{5} \mathrm{OH}: \mathrm{H}_{2} \mathrm{O}=4: 1\right.$, volume ratio) mixture was dropped onto the electrode surface to fix the $\mathrm{HP}-\mathrm{IrO}_{2}$ powder onto the GC electrode, and the electrode was dried at $60^{\circ} \mathrm{C}$ for $1 \mathrm{~h}$ in air and at room temperature for one night in the vacuum condition. The $\mathrm{HP}-\mathrm{IrO}_{2} / \mathrm{GC}$ electrode was rotated at $2000 \mathrm{rpm}$ in the voltammetry.

\section{Preparation of $\mathrm{HP}_{-} \mathrm{IrO}_{2} / \mathrm{MPTi}$ electrodes for the $\mathrm{MEAs}$}

To prepare the electrode for the MEA, a macro-porous Ti sheet, MPTi (TIPOROUS ${ }^{\circledR}$, Osaka Titanium Technologies Co., Ltd.), was used as the substrate of the oxide catalyst. First, the MPTi $(20 \mathrm{~mm} \times 20 \mathrm{~mm} \times 0.1 \mathrm{~mm})$ was etched with $10 \%$ oxalic acid at $80^{\circ} \mathrm{C}$ for $1 \mathrm{~h}$, and then rinsed with deionized water. Next, the MPTi was soaked in the coating solution (1-butanol solution containing $0.5 \mathrm{M} \mathrm{IrCl}_{3}$ and $0.21 \mathrm{M}$ $\left.\mathrm{La}\left(\mathrm{NO}_{3}\right)_{3} \cdot 6 \mathrm{H}_{2} \mathrm{O}\right)$ followed by drying $\left(60^{\circ} \mathrm{C}, 10 \mathrm{~min}\right)$ and calcination $\left(450^{\circ} \mathrm{C}, 10 \mathrm{~min}\right)$ in air. This procedure was repeated twice, and the lanthanum species were then removed using $0.5 \mathrm{M} \mathrm{H}_{2} \mathrm{SO}_{4}$ at $60^{\circ} \mathrm{C}$ for $10 \mathrm{~h}$. The electrode was then washed with distilled water 
followed by drying $\left(60^{\circ} \mathrm{C}, 30 \mathrm{~min}\right)$ in air. A typical amount of $\mathrm{HP}-\mathrm{IrO}_{2}$ loaded on the MPTi determined by gravimetry was $16 \mathrm{mg} \mathrm{cm}^{-2}$. Both the loading amount and the state of the highly porous iridium oxide, $\mathrm{HP}-\mathrm{IrO}_{2}$, coated over the MPTi have not yet been optimized because they are not easy to coat $\mathrm{HP}-\mathrm{IrO}_{2}$ in suitable thickness and state on the entire surface of the inner surface of porous titanium sheet substrate, MPTi. The optimization of the coating conditions is a future problem.

Finally, the ionomer mixture was sprayed toward the $\mathrm{HP}-\mathrm{IrO}_{2} / \mathrm{MPTi}$ electrode, and the electrode was dried at $60^{\circ} \mathrm{C}$ for $1 \mathrm{~h}$ in air at room temperature for one night in the vacuum condition. The $(\mathrm{Pt} / \mathrm{C}) \mid$ membrane $\left(\mathrm{HP}-\mathrm{IrO}_{2} / \mathrm{MPTi}\right) \mathrm{MEA}$ was prepared with the conventional Pt/C (20 wt\%, $1 \mathrm{mg} \mathrm{cm}^{-2}$, EC-20-10-7: Electro Chem. Inc.) anode, the $\mathrm{IrO}_{2} / \mathrm{MPTi}$ cathode and a Nafion ${ }^{\circledR}$ membrane $(\mathrm{N}-117)$ by pressing them under $0.7 \mathrm{MPa}$ at $130^{\circ} \mathrm{C}$ for $3 \mathrm{~min}$. The (HP-IrO $\left./ \mathrm{MPTi}\right) \mid$ membrane $\mid\left(\mathrm{HP}-\mathrm{IrO}_{2} / \mathrm{MPTi}\right) \mathrm{MEA}$ was prepared with the two $\mathrm{HP}-\mathrm{IrO}_{2} / \mathrm{MPTi}$ electrodes and a Nafion ${ }^{\circledR}$ membrane $(\mathrm{N}-117)$ by pressing them under $0.7 \mathrm{MPa}$ at $130^{\circ} \mathrm{C}$ for $3 \mathrm{~min}$. For both MEAs, carbon paper (IGRACET GDL10CA: SGL Carbon Group) was attached to the anode and cathode for the power generation test.

\section{Power generation tests}

Two different MEAs, $\quad(\mathrm{Pt} / \mathrm{C}) \mid$ membrane $\mid\left(\mathrm{HP}-\mathrm{IrO}_{2} / \mathrm{MPTi}\right) \quad$ and $\left(\mathrm{HP}-\mathrm{IrO}_{2} / \mathrm{MPTi}\right) \mid$ membrane|(HP-IrO $\left.2 / \mathrm{MPTi}\right)$, were tested under pure hydrogen and oxygen at $80^{\circ} \mathrm{C}$. The power generation tests under atmospheric pressure of $\mathrm{H}_{2}$ and $\mathrm{O}_{2}$ were carried out at a laboratory of Shinshu University and EIWA corporation separately, and the tests under $\mathrm{H}_{2}($ atmospheric pressure $+0.2 \mathrm{MPa})$ and $\mathrm{O}_{2}$ (atmospheric pressure + $0.2 \mathrm{MPa})$ were carried out at EIWA corporation. 


\section{RESULTS AND DISCUSSION}

\section{Concept of the next-generation gas-diffusion cathode}

We have been examined the ORR activity of a few oxide electrodes which were prepared by dip-coating using a titanium disk substrate[16, 17, 19]. This methodology has various benefits: (a) its preparation procedure is easy, (b) it can be applied for various kinds of oxide catalysts, (c) it needs no carbon support, (d) the oxide catalysts can be prepared at a low temperature and (e) the interface between the catalyst oxide coating and the titanium substrate is usually strong due to the formation of a mixed oxide interface layer. In this study, these benefits were utilized to prepare a novel gas-diffusion oxide cathode; that is, a macro-porous titanium sheet, MPTi, was used as the substrate of oxide catalyst layer.

To test the availability of the oxide-coated catalyst for the novel gas-diffusion electrode, we have selected the electrode coated with a highly porous iridium oxide, $\mathrm{HP}-\mathrm{IrO}_{2}$, prepared by dip-coating with the help of lanthanum oxide to form a highly porous structure[16, 17]. The reasons why we have chosen it were as follows: (a) The onset potential for the ORR, where the cathodic current for the ORR becomes clear in the cathodic potential sweep of an electrode in linear sweep voltammetry, of the $\mathrm{HP}-\mathrm{IrO}_{2} / \mathrm{Ti}$ electrode prepared at $450^{\circ} \mathrm{C}$ by dip-coating was high, $0.84 \mathrm{~V}$ vs. RHE, when determined in $0.5 \mathrm{M} \mathrm{H}_{2} \mathrm{SO}_{4}$ at $60^{\circ} \mathrm{C}$ without rotation of the electrode, while those of the valve metal oxide electrodes, $\mathrm{TiO}_{x} / \mathrm{Ti}, \mathrm{ZrO}_{x} / \mathrm{Ti}$ and $\mathrm{TaO}_{x} / \mathrm{Ti}$, prepared at $450^{\circ} \mathrm{C}$ by dip-coating were $0.91,0.81$ and $0.82 \mathrm{~V}$ vs. RHE, respectively[19], (b) The electric 
conductivity of iridium oxide is much higher than those of the valve metal oxides. The high durability of iridium oxide coatings has already been demonstrated in industry; e.g., $\mathrm{IrO}_{2}-\mathrm{Ta}_{2} \mathrm{O}_{5} / \mathrm{Ti}$ electrodes have generally been used as oxygen-evolving anodes in electroplating processes in acidic solutions[20]. A conceptual drawing of the novel cathode is shown in Fig. 1.

Figure 2 (a) shows a scanning electron microscopy (SEM) image of an as-received MPTi composed of interconnected titanium particles of 5-20 $\mu \mathrm{m}$ in diameter and 0.1 $\mathrm{mm}$ in thickness. After chemical etching of the MPTi sheet with oxalic acid solution to remove the surface titanium oxide layer (Fig. 2 (b)), the outer and inner surfaces of the MPTi were coated with an $\mathrm{HP}-\mathrm{IrO}_{2}$ layer by dip-coating. SEM images of an etched surface of the MPTi and an HP-IrO 2 /MPTi electrode are shown in Figs. 2 (c) and (d).

\section{Fundamental characteristics of $\mathrm{HP}_{-\mathrm{IrO}} \mathrm{O}_{2}$ coated on a Ti disk substrate}

Prior to clarifying the fundamental characteristics of the $\mathrm{HP}-\mathrm{IrO}_{2}$ catalyst layer coated on the MPTi, a few basic characteristics of the $\mathrm{HP}-\mathrm{IrO}_{2}$ catalyst coating were examined using an $\mathrm{HP}-\mathrm{IrO}_{2} / \mathrm{Ti}$ electrode with a non-porous titanium disk substrate, Ti. Figure 3 shows cyclic voltammograms of an $\mathrm{HP}-\mathrm{IrO}_{2} / \mathrm{Ti}$ before and after the severe durability test $\left(10,000\right.$ potential cycles of the test electrode in $\mathrm{O}_{2}$-saturated solution between 1.0 and $1.5 \mathrm{~V}$ vs. RHE at $500 \mathrm{mV} \mathrm{s}^{-1}$ at $30^{\circ} \mathrm{C}$ ). As shown in these voltammograms, little change of the pseudo-capacitance was observed even after the 10,000 times of potential cycling. In Fig. 4, linear sweep voltammograms (LSVs) for the ORR of an $\mathrm{HP}-\mathrm{IrO}_{2} / \mathrm{Ti}$ before and after the durability test are presented. The fact that a limiting current was not observed even at 3,000 rpm strongly suggests that the $\mathrm{HP}-\mathrm{IrO}_{2}$ layer had a highly porous structure which was too small to easily contribute to 
the ORR, other than larger pores which could easily contribute to the ORR in the solution. The specific activity, the current density per geometric surface area, at $0.75 \mathrm{~V}$ vs. RHE at 3,000 rpm was $-0.90 \mathrm{~mA} \mathrm{~cm}^{-2}$ (geometric).

Even after 10,000 potential cycles of the $\mathrm{HP}-\mathrm{IrO}_{2} / \mathrm{Ti}$ electrode between 1.0 and 1.5 $\mathrm{V}$ vs. RHE at $500 \mathrm{mV} \mathrm{s}^{-1}$, there was only a $7 \%\left(0.06 \mathrm{~mA} \mathrm{~cm}^{-2}\right.$ (apparent) $)$ decrease in the current density of the electrode for the ORR at $0.75 \mathrm{~V}$ vs. RHE. The reason why the catalytic activity for the ORR decreased by $7 \%$ in spite of the little change in the pseudo-capacitance after the durability test is unclear at present. In any case, the electrode was proved to be highly durable, although the high durability of iridium oxide coatings has already been well-documented, provided that the coatings have been prepared by the appropriate procedure. The ORR on the $\mathrm{HP}-\mathrm{IrO}_{2}$ obeyed the 4-electrons reaction over a wide range of potentials, as determined by a rotating ring disk electrode method (Fig. 5).

The performance of a PEFC with an MEA using a Pt/C anode and $\mathrm{HP}-\mathrm{IrO}_{2} / \mathrm{MPTi}$ cathode

The $I-E$ and $I-W$ curves for a $(\mathrm{Pt} / \mathrm{C}) \mid$ membrane $\mid\left(\mathrm{HP}-\mathrm{IrO}_{2} / \mathrm{MPTi}\right)$ fuel cell under pure oxygen (atmospheric pressure) and hydrogen (atmospheric pressure) at $80^{\circ} \mathrm{C}$ is shown in Fig. 6. As demonstrated in this figure, considerable electric power was successfully generated with the PEFC, although the performance was not high enough for the practical use at present. The cell voltage at zero net current of the fuel cell including the overvoltage other than the electric motive force of the cell and the maximum power density were $0.89 \mathrm{~V}$ and $42 \mathrm{~mW} \mathrm{~cm}^{-2}$, respectively. Here we denote the cell voltage at zero net current of the fuel cell as CVZC, which is often described with OCV (Open 
Circuit Voltage). Although conditions for preparing the $\mathrm{HP}-\mathrm{IrO}_{2} / \mathrm{MPTi}$ cathode have not yet been optimized, the high values of both the CVZC and the power density are noteworthy.

\section{Fundamental HOR characteristics of the $\mathrm{HP}-\mathrm{IrO}_{2} / \mathrm{Ti}$ electrode}

In order to prove the possibility of a PEFC, where both cathode and anode are composed of oxide-coated gas-diffusion electrodes, the anodic characteristics for the hydrogen oxidation reaction, $\mathrm{HOR}$, of the $\mathrm{HP}-\mathrm{IrO}_{2}$ catalyst layer were examined using an $\mathrm{HP}-\mathrm{IrO}_{2} / \mathrm{Ti}$ electrode as an oxide anode. As shown in Fig. 7, the $\mathrm{HP}-\mathrm{IrO}_{2} / \mathrm{Ti}$ electrode showed catalytic activity towards both the reduction of $\mathrm{H}^{+}[21,22]$ and the oxidation of hydrogen in $0.1 \mathrm{M} \mathrm{HClO}_{4}$ at $30^{\circ} \mathrm{C}$, where the $\mathrm{LSV}$ curves depended on the initial electrode potential in the potential sweep to the positive potential. The $\mathrm{HP}-\mathrm{IrO}_{2} / \mathrm{Ti}$ electrode provides high catalytic activity for the $\mathrm{HOR}$ at $3,000 \mathrm{rpm}$; the current density for the HOR at $0.01 \mathrm{~V}$ vs. RHE was $0.63 \mathrm{~mA} \mathrm{~cm}^{-2}$ (geometric).

As a result, the HP- $\mathrm{IrO}_{2}$ has been found to have catalytic activity for the HOR. Therefore, an MEA was assembled with $\mathrm{HP}-\mathrm{IrO}_{2} / \mathrm{MPTi}$ electrodes not only as the cathode, but also as the anode of a PEFC: (HP-IrO $2 / \mathrm{MPTi}) \mid$ membrane|(HP-IrO $/ \mathrm{MPTi})$.

The performance of a PEFC with HP-IrO $\mathrm{O}_{2}$ MPTi electrodes both for the cathode and the anode

The $I-E$ and $I-W$ curves for a $\left(\mathrm{HP}-\mathrm{IrO}_{2} / \mathrm{MPTi}\right) \mid$ membrane|(HP-IrO $\left.\mathrm{I}_{2} / \mathrm{MPTi}\right)$ fuel cell under pure oxygen (atmospheric pressure) and hydrogen (atmospheric pressure) at $80^{\circ} \mathrm{C}$ is shown in Fig. 8. The CVZC and the maximum power density were $0.86 \mathrm{~V}$ and 34 $\mathrm{mW} \mathrm{cm}{ }^{-2}$, respectively. Under pure $\mathrm{O}_{2}(+0.2 \mathrm{MPa})$ and $\mathrm{H}_{2}(+0.2 \mathrm{MPa})$, however, the 
CVZC and the maximum power density improved to $0.91 \mathrm{~V}$ and $74 \mathrm{mWcm}^{-2}$, respectively. Under pure $\mathrm{O}_{2}(+0.2 \mathrm{MPa})$ and $\mathrm{H}_{2}(+0.2 \mathrm{MPa})$, however, the CVZC and the maximum power density improved to $0.91 \mathrm{~V}$ and $74 \mathrm{~mW} \mathrm{~cm}{ }^{-2}$, respectively. The success of the generation of this fuel cell is significant; however, the performance was not high enough for the practical use at present. Although the $\mathrm{HP}-\mathrm{IrO}_{2} / \mathrm{MPTi}$ electrode has been demonstrated to act also as the anode of the PEFC, not only iridium is expensive material but adaptation of the electrode to the anode of PEFCs requires a more detailed examination of the durability.

\section{The role of oxide ion vacancy in the oxide-coated gas-diffusion electrode}

To design highly active gas-diffusion electrodes, it is important to guarantee the electrical conduction through the current collector to the catalyst surface. The gas-diffusion cathode proposed in this study, the electrical resistance of the MPTi support, which is the current collector itself, is composed of interconnected titanium micro-particles, and hence, the electrical resistance of the MPTi sheet is negligible. Electrical resistance occurs mainly (a) through the bulk of the oxide catalyst particles themselves and the interface between the oxide catalyst particles connecting to each other to form the oxide catalyst layer, and (b) at the interface between the oxide catalyst layer and the titanium support. For the $\mathrm{HP}-\mathrm{IrO}_{2} / \mathrm{MPTi}$ electrode, the resistance from (a) and (b) are unlikely to be high, because $\mathrm{IrO}_{2}$ exhibits metallic conductivity. Even if an oxide catalyst does not have metallic conductivity, the oxide-coated titanium electrode acts as a catalyst electrode, provided the oxide layer is thin and contains many oxide ion vacancies. The oxide ion vacancy in metal oxides can generally be created by heating them or by heating them in vacuum at a high temperature; however, vacancies are also 
created for the oxides prepared by calcination of precursors at low temperature, e.g., $450^{\circ} \mathrm{C}$. In spite of the considerably low electric conductivity of the valve metal oxides coated on a Ti disk substrate: $\mathrm{TiO}_{x} / \mathrm{Ti}, \mathrm{ZrO}_{x} / \mathrm{Ti}$ and $\mathrm{TaO}_{x} / \mathrm{Ti}$, all these oxide-coated electrodes showed high catalytic activity for the ORR[19]. This suggests that the oxide ion vacancy in these oxides was stable under the polarization. Moreover, heat-treatment of the oxides under a reducible atmosphere, e.g., under hydrogen, increases not only the amount of oxide ion vacancies but also the electric conductivity, as has been utilized to control the electric properties of n-type titanium dioxides, $\mathrm{TiO}_{2-x}$. The oxide ion vacancy may act as the active sites for the $\operatorname{ORR}[14,17,19]$; that is, the electron density of the surface metal ions surrounding the oxide ion vacancy will be enhanced compared to the other normal metal ions on the surface, and they may behave as adsorption sites for oxygen molecules[23]. Concerning the potential for resistance (b) pointed out above, the interface between the oxide coating and the titanium support formed by the dip-coating is usually stable; that is, the oxide coating adheres to the titanium substrate strongly, forming a mixed oxide interface layer.

\section{SUMMARY}

In conclusion, this study demonstrated successful power generations of PEFCs with a substantially novel oxide-coated gas-diffusion cathode. The important results of this study are as follows: (a) A gas-diffusion electrode composed of oxide catalyst, a highly porous iridium oxide in this study, which was strongly coated on inner and outer surfaces of a macro porous titanium sheet substrate has been reported for the first time. (b) The oxide-coated gas-diffusion electrode using neither platinum catalyst nor carbon 
support has functioned not only as the cathode but the anode of PEFCs. (c) The ORR on the $\mathrm{HP}-\mathrm{IrO}_{2}$ obeyed the 4-electrons reaction over a wide range of potentials. (d) It has been found that $\mathrm{IrO}_{2}$ shows catalytic activity for the oxidation of hydrogen in acidic solution. (e) The PEFCs composed of two different MEAs, $(\mathrm{Pt} / \mathrm{C}) \mid$ membrane|(HP- $\left.\mathrm{IrO}_{2} / \mathrm{MPTi}\right) \quad$ and $\quad\left(\mathrm{HP}-\mathrm{IrO}_{2} / \mathrm{MPTi}\right) \mid$ membrane|(HP-IrO $\left.2 / \mathrm{MPTi}\right)$, have functioned well.

This type of gas-diffusion electrode should be widely studied in order to realize stable and highly reliable PEFCs; however, the iridium oxide electro-catalyst, which was used as a test oxide catalyst of this gas-diffusion electrode should be replaced by a less-expensive oxide catalyst in near future. Our approach to creating novel gas-diffusion cathodes may pave the way for the worldwide development of PEFCs, although the performance of the cathode still needs to be improved. Other than the search for a less-expensive catalyst providing high catalytic activity for the ORR, the macro-porous metal support should also be improved; i.e., the MPTi sheet support must be made thinner, and the inner specific surface area of the MPTi sheet should be larger to allow it to carry more oxide catalyst.

\section{Acknowledgments}

This work was supported in part by the "Polymer Electrolyte Fuel Cell Program; Development of Next Generation Technology" project of the New Energy and Industrial Technology Development Organization (NEDO) of Japan. We also express thanks to Dr. Yoshinori Nishiki of the PERMELEC ELECTRODE, LTD for his useful suggestion. 


\section{REFERENCES}

1. M. Z. Jacobson, W. G. Colella and D. M. Golden, Science 308, 1901 (2005).

2. B. C. H. Steele and A. Heinzel, Nature 414, 345 (2002).

3. H. A. Gasteiger, S .K. Kocha, B. Sompalli and F. T. Wagner, Appl. Catal. B: Environmental 56, 9 (2005).

4. J. Zhang, K. Sasaki, E. Sutter and R. R. Adzic, Science 315, 220 (2007).

5. P. J. Ferreira, G. J. la O', Y. Shao-Horn, D. Morgan, R. Makharia, et al., J. electrochem. Soc. 152, A2256 (2005).

6. S. Maass, F. Finsterwalder, G. Frank, R. Hartmann and C. Merten, J. Power Sources 176, 444 (2008).

7. F. Ettingshausen, J. Kleemann, A. Marcu, G. Toth, H. Fuess, et al., Fuel Cells 11, 238 (2011).

8. M. Lefevre, E.Proietti, F. Jaoouen and J.-P. Dodelet, Science 324, 71 (2009).

9. S. M. Lyth, Y. Nabae, S. Moriya, S. Kuroki, M. Kakimoto, et al. J. phys. Chem. C 113, 20148 (2009).

10. K. Gong, F. Du, Z. Xia, M. Durstock and L. Dai, Science 323, 760 (2009).

11. G. Liu, X. Li, P. Ganesan and B. N. Popov, Electrochim. Acta 55, 2853 (2010).

12. G. Wu, K. L. More, C. M. Jhonson and P. Zelenay, Science 332, 443 (2011).

13. A. Ishihara, K. Lee, S. Doi, S. Mitsushima, K. Kamiya, et al., Electrochem. Solid-State Lett. 8, A201 (2005).

14. K.-I. Ota, Y. Ohgi, K.-D. Nam, S. Mitsushima, et al., J. Power Sources 196, 5256 (2011).

15. J. Y. Kim, T.-K. Oh, Y. Shin, J. Bonnett and K. S. Weil, Int. J. Hydrogen Energy 36, 
4557 (2011).

16. Y. Takasu, N. Yoshinaga and W. Sugimoto, Electrochem. Commun. 10, 668 (2008).

17. N. Yoshinaga, W. Sugimoto and Y. Takasu, Electrochim. Acta 54, 566 (2008).

18. J. Seo, D. Cha, K. Takanabe, J. Kubota and K. Domen, Chem. Commun. 48, 9074 (2012).

19. Y. Takasu, M. Suzuki, H. Yang, T. Ohashi and W. Sugimoto, Electrochim. Acta 55, 8220 (2010).

20. S. Trasatti, Electrochim. Acta 45, 2377 (2000).

21. Th. Pauporte, F. Androlfatto, R. Durand, Electrochim. Acta 45, 431 (1999).

22. T. Ioroi, N. Kitzawa, K. Yasuda, Y. Yamamoto, H. Takenaka, J. electrochem. Soc. 147, 2018 (2000).

23. E. Hendry, F. Wang, J. Shan, T.F. Heinz, M. Bonn, Phys. Rev. B 69, 811011 (2004).

\section{Figure captions}

Fig. 1. A conceptual drawing of an $\mathrm{HP}-\mathrm{IrO}_{2} / \mathrm{MPTi}$ cathode.

Fig. 2. (a) An SEM image of the as-received macro-porous Ti sheet substrate, MPTi. (b) The MPTi after being chemically etched with oxalic acid solution. (c) and (d) SEM images of an $\mathrm{HP}-\mathrm{IrO}_{2} / \mathrm{MPTi}$ electrode observed at two different magnifications.

Fig. 3. Cyclic voltammograms of the $\mathrm{HP}-\mathrm{IrO}_{2} / \mathrm{Ti}$ electrode showing the durability of the electrode after repetitive potential cycles between $1.0 \mathrm{~V}$ and $1.5 \mathrm{~V}$ vs. RHE at $500 \mathrm{mV}$ $\mathrm{s}^{-1}$ in $\mathrm{O}_{2}$-saturated $0.1 \mathrm{M} \mathrm{HClO}_{4}$ at $30^{\circ} \mathrm{C}$. The number of potential cycles: a; the first sweep after the pre-treatment, b; 100 times, c; 1,000 times, d: 10,000 times. 
Fig. 4. Linear sweep voltammograms for the ORR (a) before and (b) after the durability test $\left(10,000\right.$ potential cycles of the test electrode in $\mathrm{O}_{2}$-saturated solution between 1.0 and $1.5 \mathrm{~V}$ vs. $\mathrm{RHE}$ at $500 \mathrm{mV} \mathrm{s}^{-1}$ ) of an $\mathrm{HR}-\mathrm{IrO}_{2} / \mathrm{Ti}$ electrode at $30^{\circ} \mathrm{C}$. The rotating speed of the electrode in $\mathrm{O}_{2}$-saturated solution for (a) and (b): a; 0, b; 500, c; 1,000, d; 1,500, e; 2,000, f; 2,500, g; 3,000 rpm.

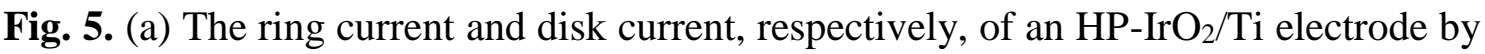
the RRDE in $\mathrm{O}_{2}$-saturated $0.1 \mathrm{M} \mathrm{HClO}_{4}$ at $30^{\circ} \mathrm{C}$ at the test electrode rotating speed of 2,000 rpm. (c) Number of electrons contributing to the reduction of one oxygen atom on the $\mathrm{HP}-\mathrm{IrO}_{2} / \mathrm{Ti}$ electrode calculated from the voltammograms of (a) and (b).

Fig. 6. The cell voltage and power density vs. current density for a PEFC: (Pt/C, 20 wt\%Pt)|(membrane, Nafion ${ }^{\circledR}$ 117)|(HP-IrO $/$ MPTi), under pure $\mathrm{H}_{2}$ (atmospheric pressure) and pure $\mathrm{O}_{2}$ (atmospheric pressure) at $80^{\circ} \mathrm{C}$.

Fig. 7. (a) Linear sweep voltammograms of an $\mathrm{HP}-\mathrm{IrO}_{2} / \mathrm{Ti}$ for the $\mathrm{HOR}$ at the anodic potential sweep rate of $5 \mathrm{mV} \mathrm{s}^{-1}$ in $0.1 \mathrm{M} \mathrm{HClO}_{4}$ at $30^{\circ} \mathrm{C}$. a; a $\mathrm{LSV}$ measured in $\mathrm{N}_{2}$-saturated $0.1 \mathrm{M} \mathrm{HClO}_{4}$. The rotating speed of the electrode in $\mathrm{H}_{2}$-saturated solution: b; 0, c; 500, d; 1,000, e; 1,500, f; 2,000, g; 2,500, h; 3,000 rpm.

Fig. 8. The cell voltage and power density vs. current density for the PEFC: $\left(\mathrm{HP}-\mathrm{IrO}_{2} / \mathrm{MPTi}\right) \mid$ membrane $\left(\mathrm{Nafion}^{\circledR}{ }^{\circledR} 117\right) \mid\left(\mathrm{HP}-\mathrm{IrO}_{2} / \mathrm{MPTi}\right)$, under pure $\mathrm{O}_{2}$ (atmospheric pressure) and $\mathrm{H}_{2}$ (atmospheric pressure) at $80^{\circ} \mathrm{C}$ (squares; $\square$ and $\boldsymbol{\square}$ ) or under pure $\mathrm{O}_{2}$ (atmospheric pressure $+0.2 \mathrm{MPa}$ ) and $\mathrm{H}_{2}$ (atmospheric pressure +0.2 $\mathrm{MPa})$ at $80^{\circ} \mathrm{C}$ (circles; $\circ$ and $\left.\bullet\right)$. 


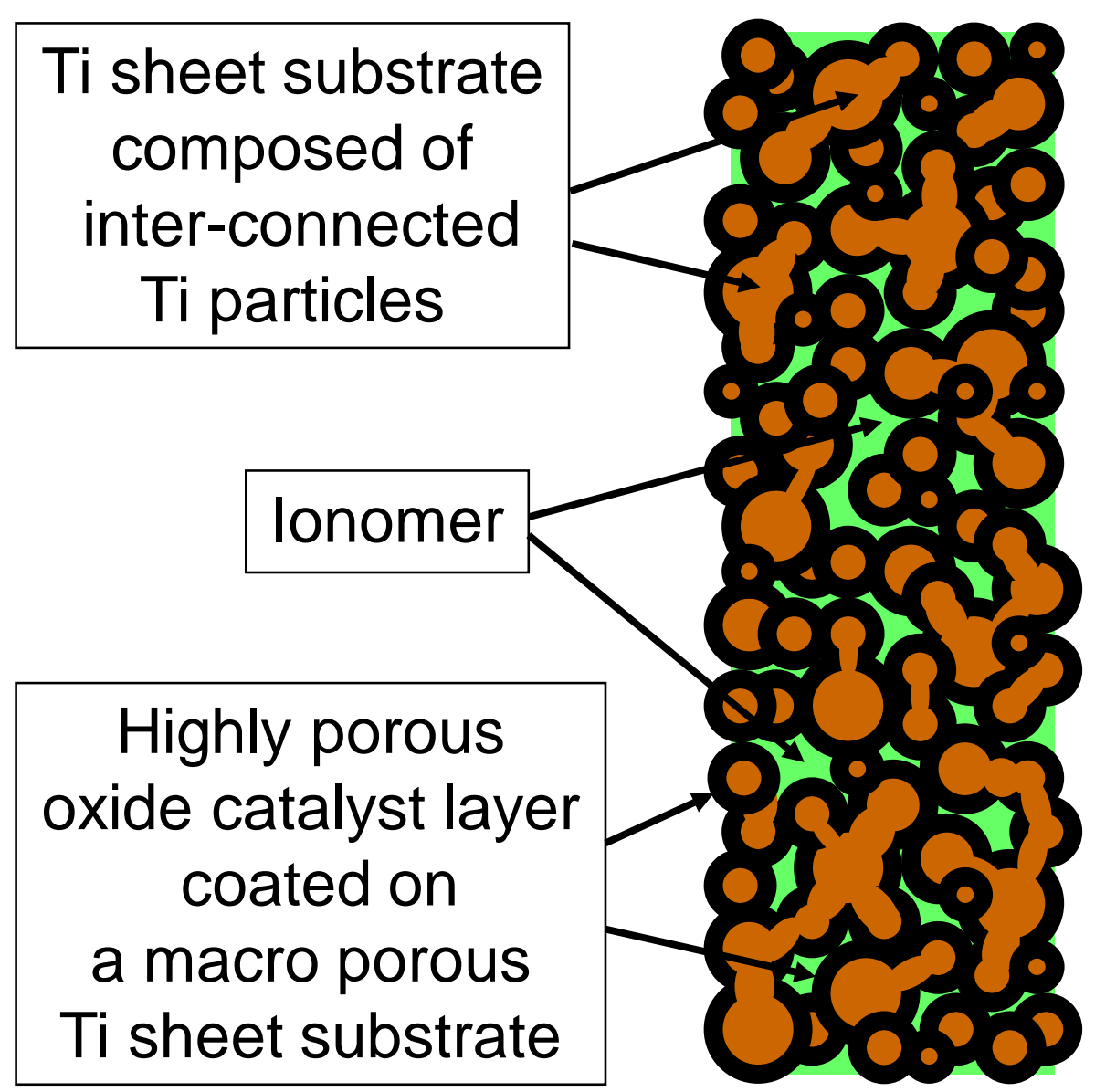

Y. Takasu, et al. Fig. 1 

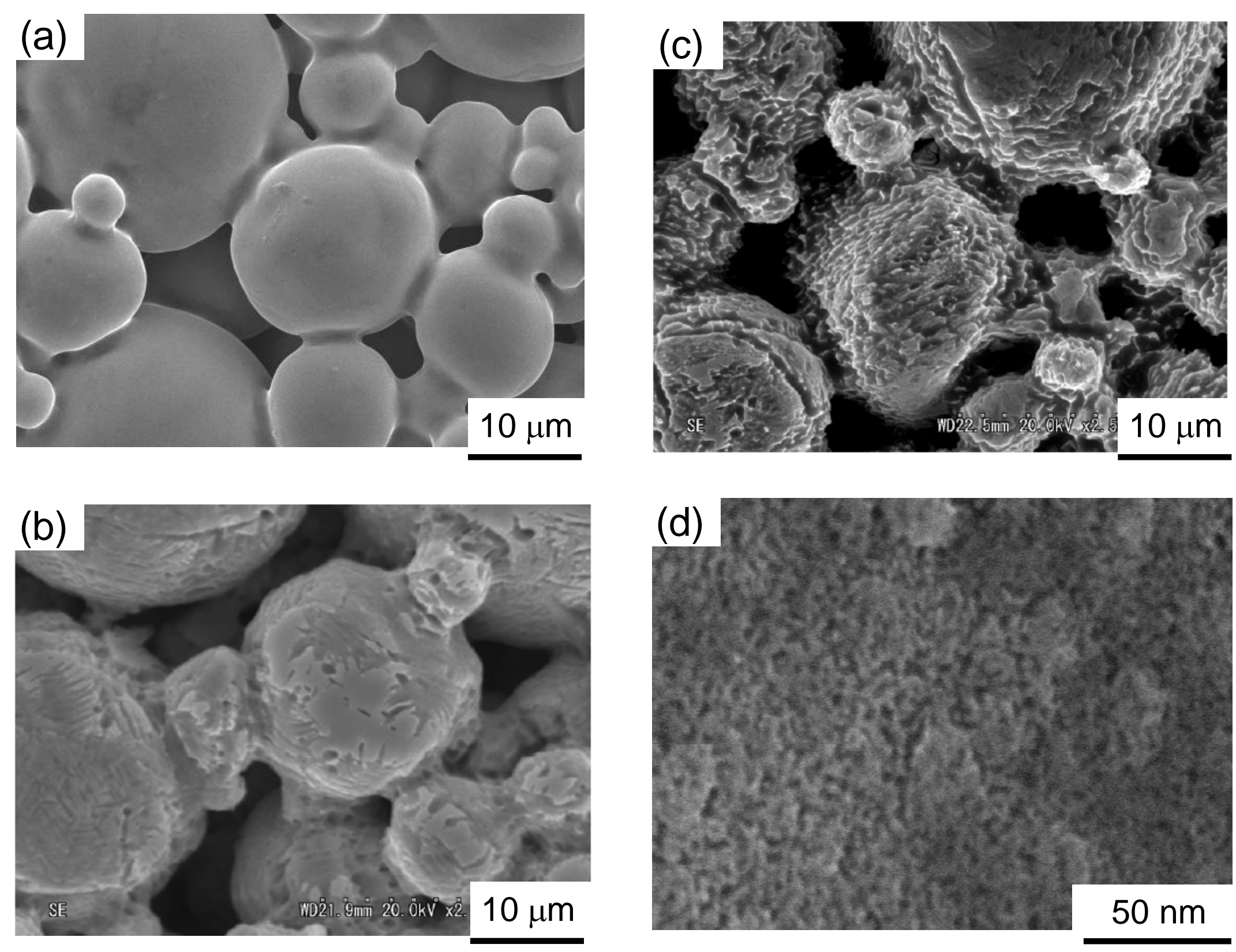

Y. Takasu, et al. Fig. 2 


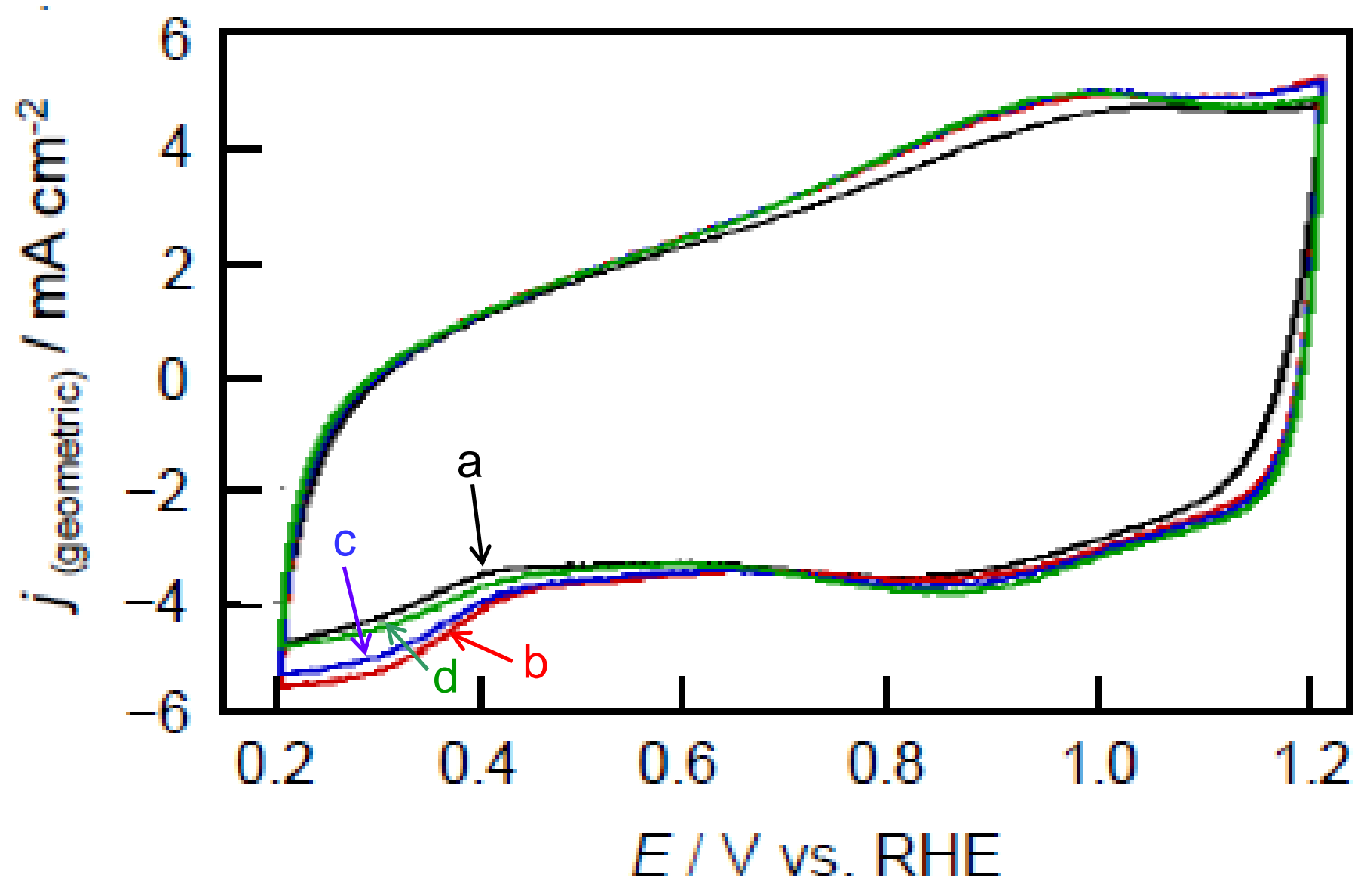

Y. Takasu, et al. Fig. 3 
(a)

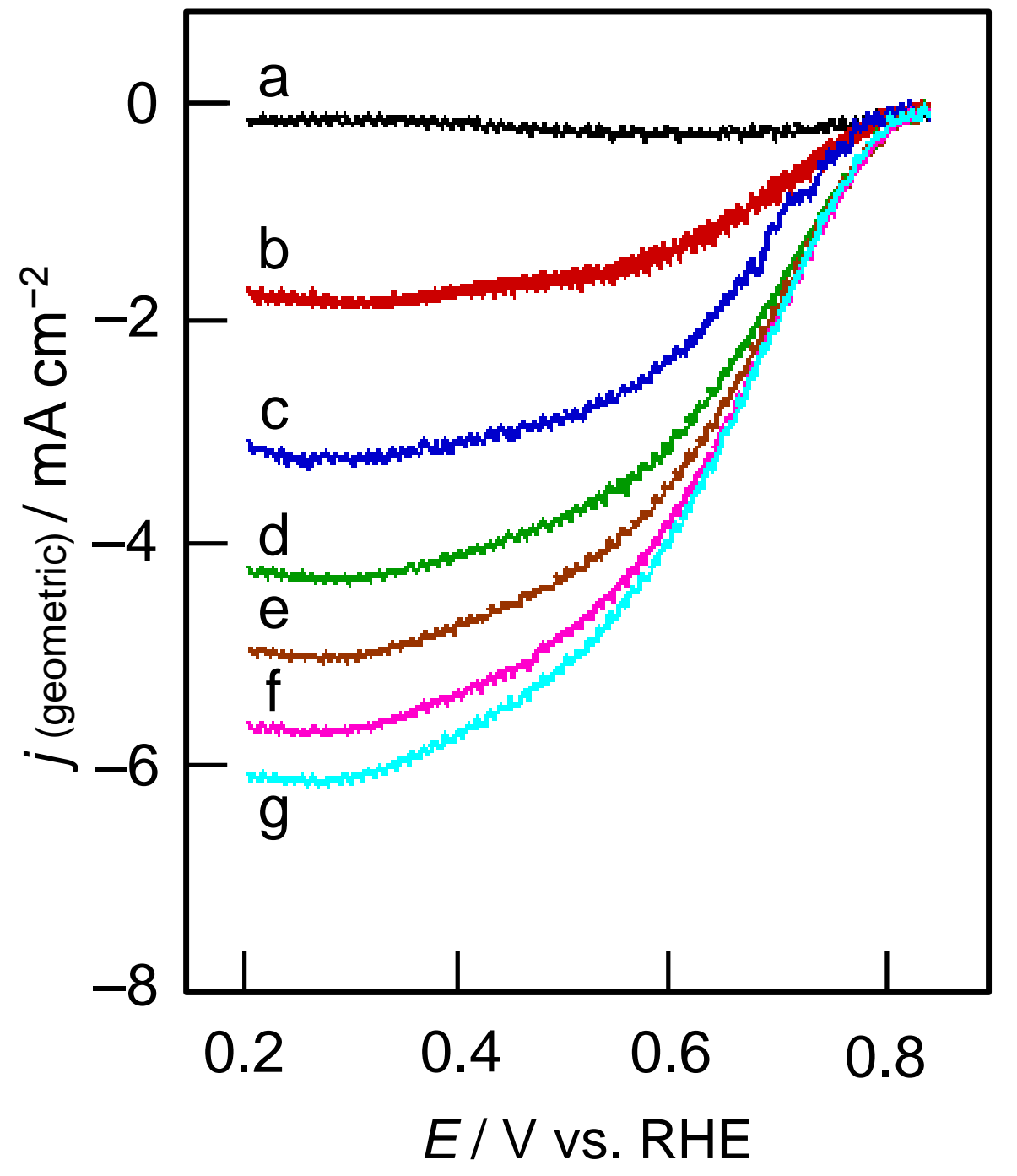

(b)

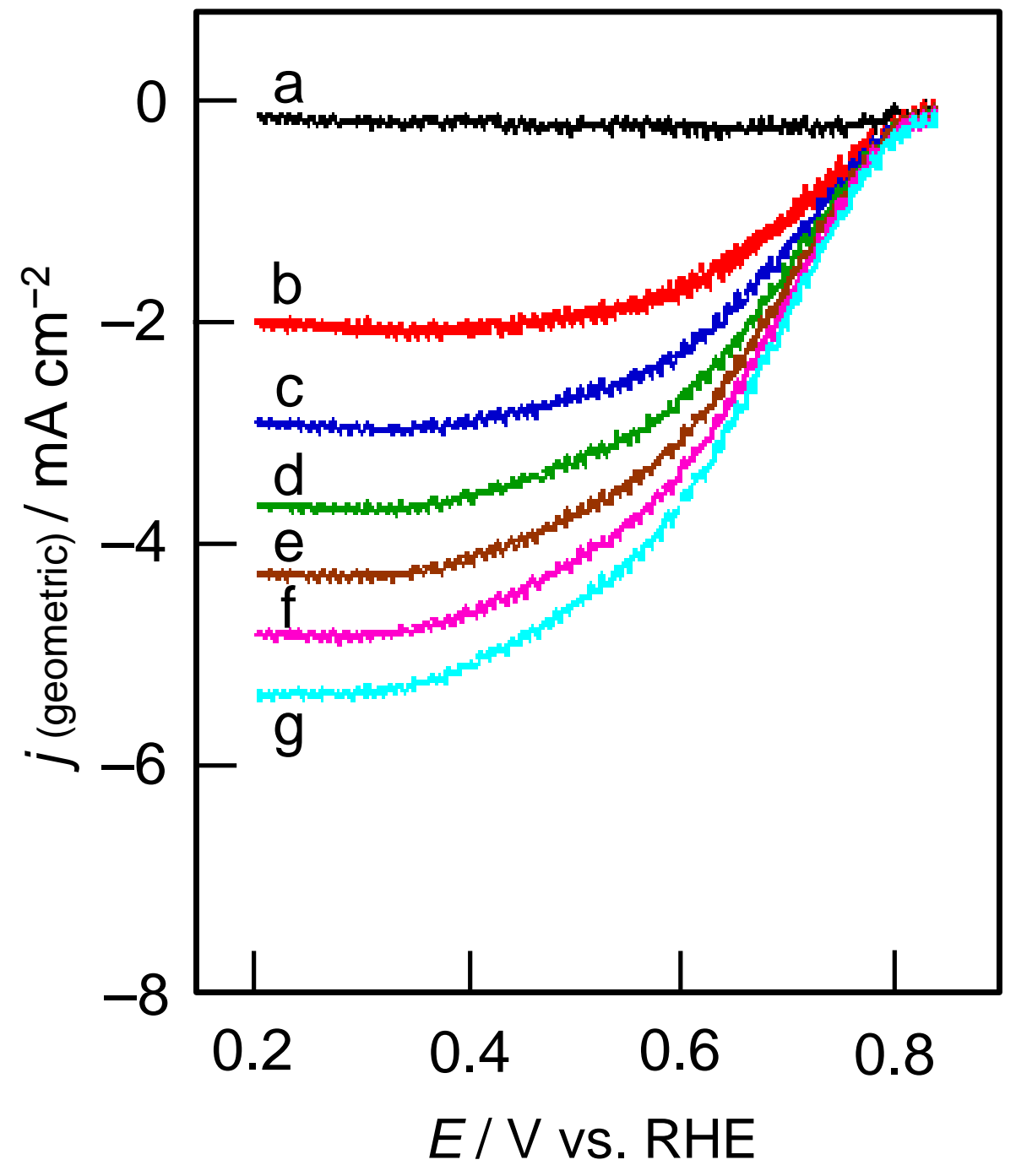

Y. Takasu, et al. Fig. 4 
(a)
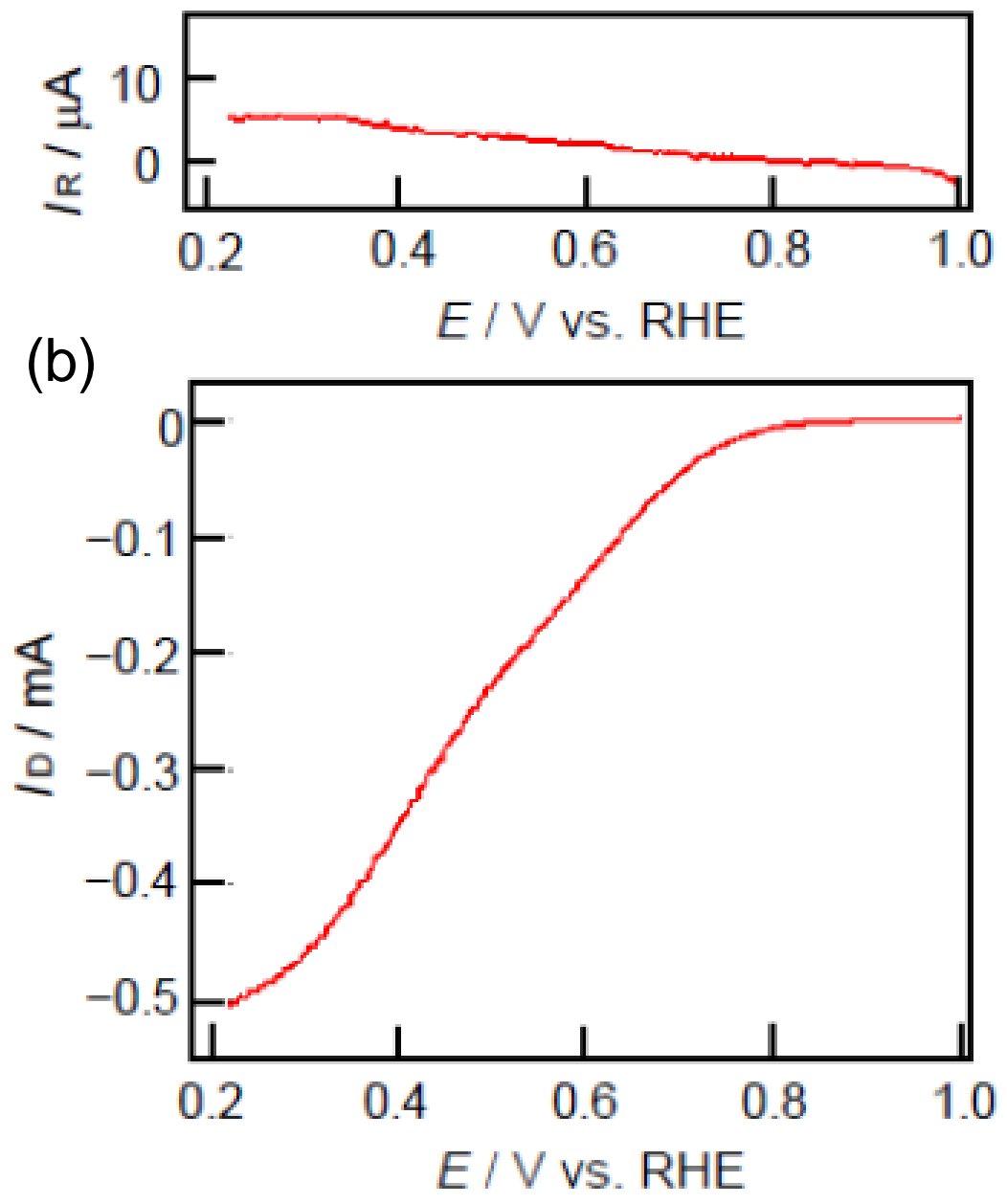

(c)

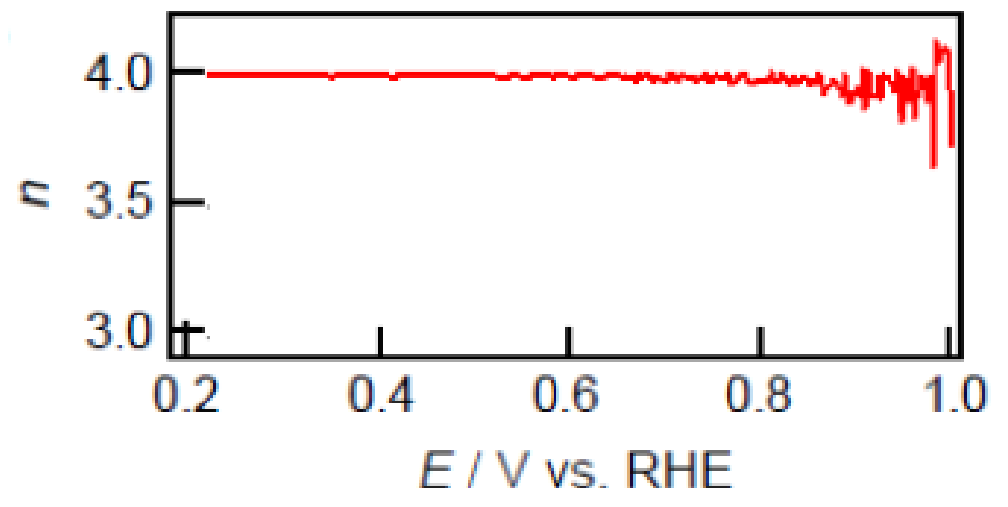




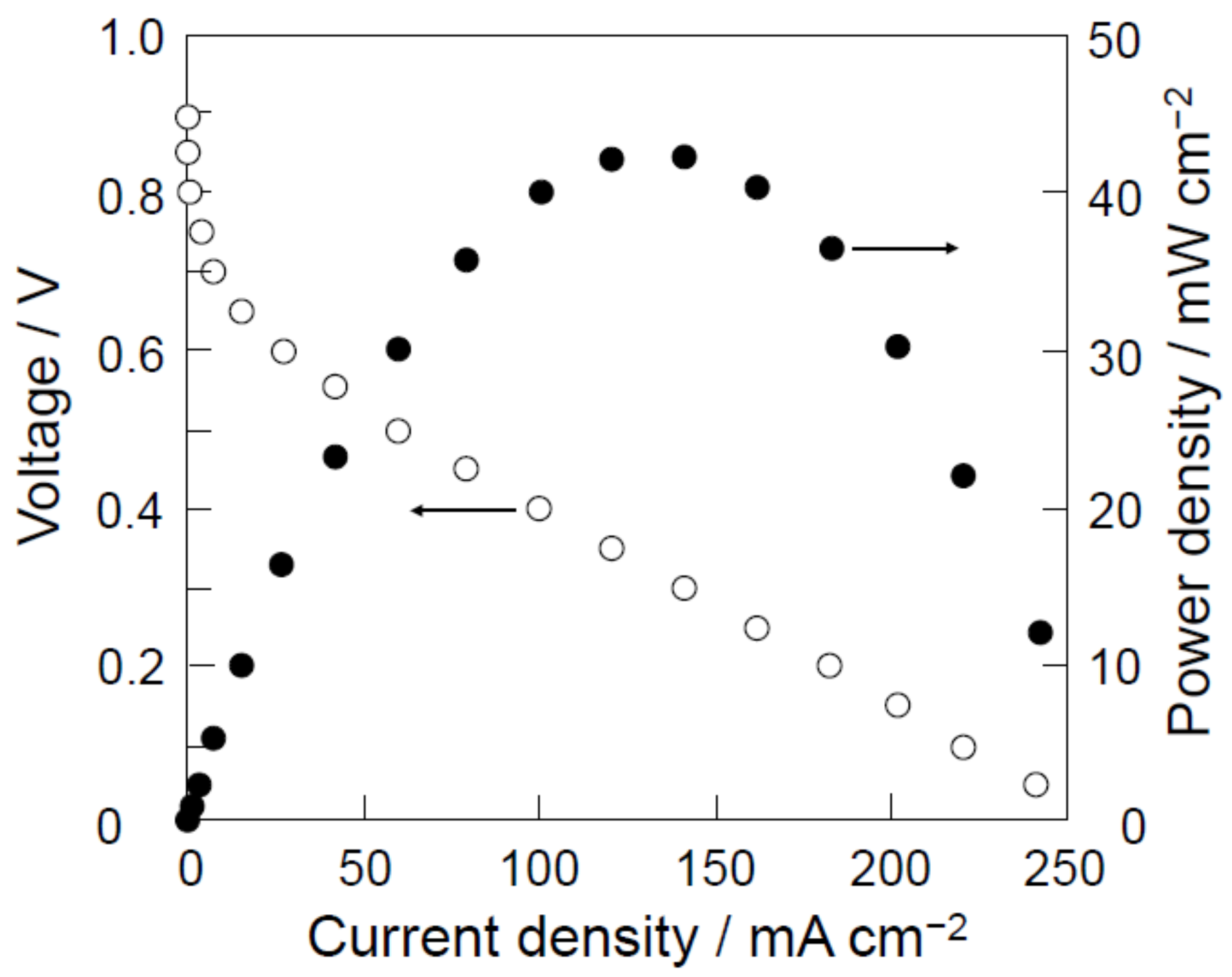

Y. Takasu, et al. Fig. 6 


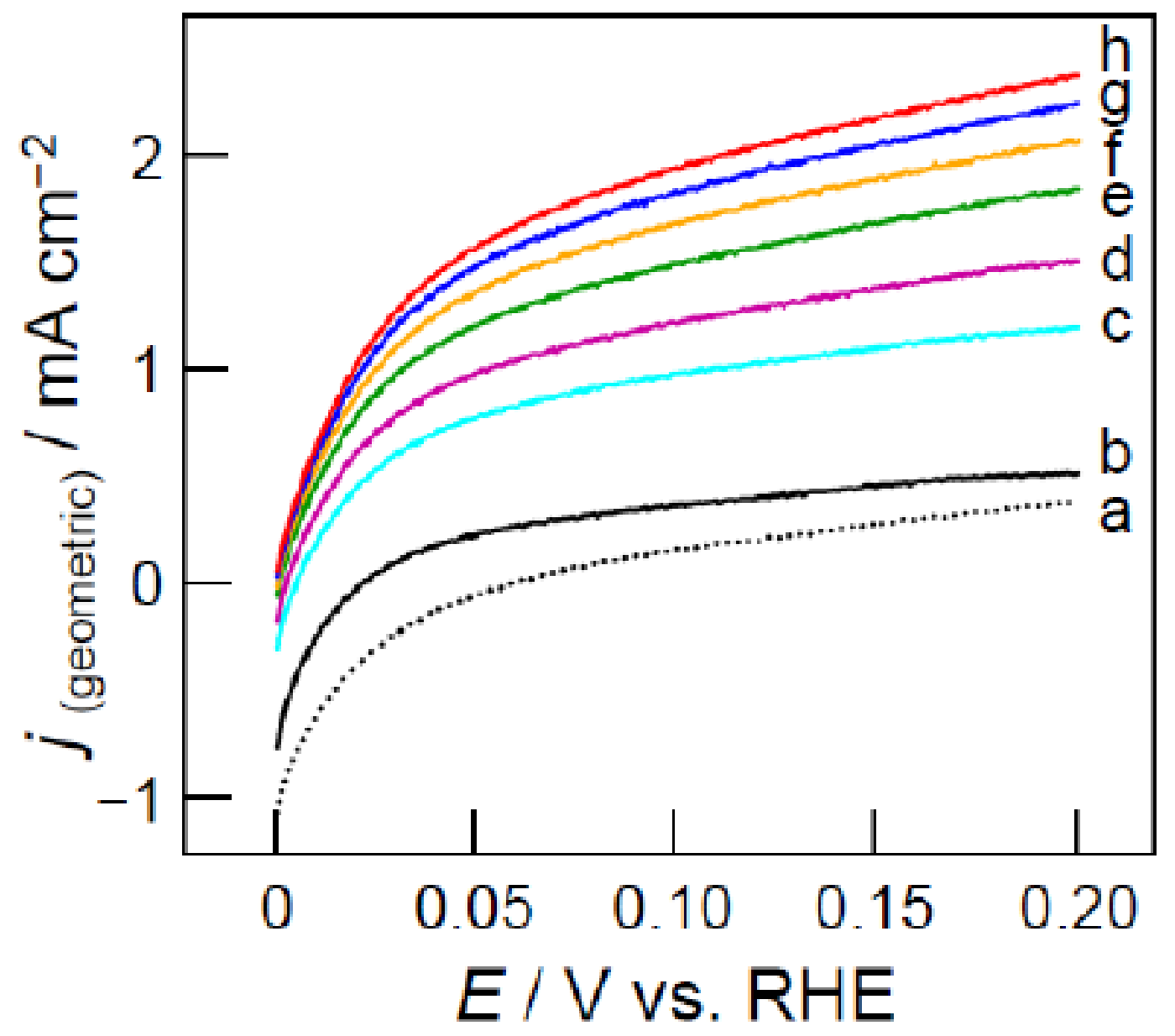

Y. Takasu, et al. Fig. 7 


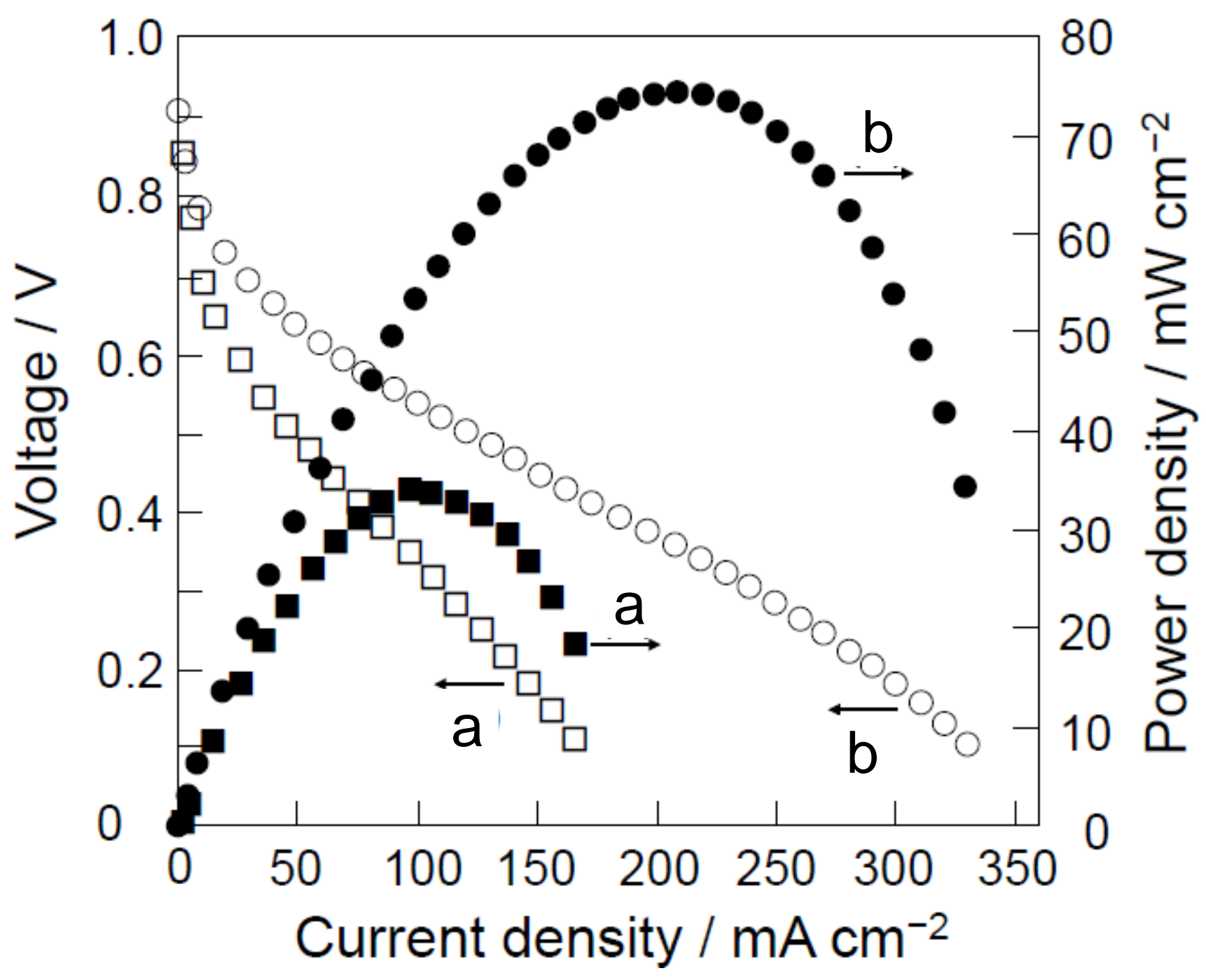

Y. Takasu, et al. Fig. 8 